\title{
IMPLEMENTASI PEMBELAJARAN BERBASIS STEM UNTUK MENINGKATKAN KEMAMPUAN DALAM BERPIKIR KRITIS, KREATIF DAN BEKERJASAMA PESERTA DIDIK KELAS VIIA SMP NEGERI 4 SIBULUE
}

\author{
*Suardi \\ SMP Negeri 4 Sibulue \\ Suardi74@gmail.com
}

*koresponden author
Abstrak - Implementasi Pembelajaran Berbasis STEM dalam Meningkatkan Kemampuan Siswa dalam Berpikir Kritis, Kreatif dan Bekerjasama. Penelitian bertujuan untuk memperoleh gambaran tentang: 1) peningkatan kemampuan berpikir kritis peserta didik; 2) peningkatan kemampuan berpikir kreatif; 3) peningkatan kerjasama. Pada Penelitian ini digunakan teknik pengumpulan data denganmenggunakan pretes dan postes untuk mengukur pemahaman konsepdan kemampuan berpikir kritis dan kreatif peserta didik. Selain itu dilakukan dengan teknik observasi. Hasil peneliian menunjukkan bahwa kemampuan berpikir kritis peserta didik setelah diimplementasikan unit pembelajaran STEM meningkat; kemampuan berpikir kreatif juga meningkat; dan kemampuan kerja sama peserta didik juga meningkat.

Kata Kunci : STEM, berpikir kritis dan kreatif, bekerjasama

Abstract Implementation of STEM Based Learning to Know Students' Ability in Critical, Creative and Cooperative Thinking. The research aims to obtain a description of improvement: 1) students' critical thinking skills; 2) creative thinking skills; 3) cooperation ability. In this study data collection techniques were used by using pretest and posttest to measure students 'understanding of concepts and students' critical and creative thinking skills. Besides that, it is done by observation technique. The results of the study showed that the students' critical thinking skills after the STEM learning unit was implemented increased; creative thinking ability also increases; and the ability of students to work together also increases.

Keywords : STEM, critical and creative thinking, coopration participants 


\section{A. PENDAHULUAN}

Ilmu Pengetahuan Alam sebagai suatu disiplin ilmu yang hakikatnya merupakan pengetahuan yang berdasarkan fakta, hasil pemikiran para ahli dan hasil-hasil eksperimen yang dilakukan para ahli. Selanjutnya perkembangan Ilmu Pegetahuan Alam (IPA) ditunjukkan oleh produk ilmiah berupa fakta, teori, konsep dan generalisasi. Seiring dengan itu berkembang juga metode ilmiah dan sikap ilmiah.

IPA merupakan salah satu mata pelajaran yang dipelajari di SMP/MTs yang termuat dalam kurikulum. Adapun kurikulum yang digunakan sekarang adalah Kurikulum 2013 (K-13). Kurikulum 2013 menekankan pada prinsip belajar sepanjang hayat (learning for life) yang mengacu pada empat pilar pendidikan universal, yaitu: (1) belajar mengetahui (learning to know), (2) belajar melakukan (learning to do) (3) belajar menjadi diri sendiri (learning to be oneself) dan (4) belajar hidup dalam kebersamaan (learning to live together). Prinsip utama dalam proses pembelajaran adalah adanya proses keterlibatan seluruh atau sebagian besar potensi dari diri peserta didik dan kebermaknaan bagi diri dan kehidupannya saat ini dan dimasa yang akan datang. IPA dalam proses pembelajarannya lebih diarahkan pada pengembangan kemampuan intelektual serta keterampilan berpikir dan kemampuan pemahaman konsep yang lebih baik. Hal ini ditujukan pada peserta didik sebagai bekal untuk pendidikan selanjutnya. Pembelajaran IPA yang berada di SMP merupakan pembelajaran yang dapat menumbuh kembangkan keterampilan berpikir kritis peserta didik dan pembelajaran IPA dapat mengasah keterampilan-keterampilan berpikir kritis (KBK) peserta didik dalam proses pembelajaran.

Keterampilan berpikir kritis (KBK) dan keterampilan berpikir kritis peserta didik merupakan dua aspek dari beberapa aspek yang harus dilatih dan dikembangkan oleh peserta didik yang nantinya dapat dijadikan peserta didik untuk menyelesaikan atau memecahkan persoalan-persoalan yang didapatkan pada pembelajaran IPA. Keterampilan berpikir kritis penting untuk dilatihkan pada peserta didik. Menurut Johnson (2002) Berpikir kritis adalah hobi berpikir yang bisa dikembangkan oleh setiap orang, maka hobi ini harus diajarkan disekolah dasar, SMP, dan SMA. Hal serupa dikatakan oleh Cindy (2001) mengenai pentingnya berpikir kritis dalam pembelajaran yaitu penting bagi peserta didik untuk menjadi seorang pemikir mandiri sejalan dengan meningkatknya jenis pekerjaan handal yang memiliki keterampilan berpikir kritis.

Berpikir kritis tidak hanya sekedar menerima informasi dari pihak lain, tapi juga melakukan pencarian, dan bila diperlukan akan menangguhkan keputusan sampai yakin bahwa informasi itu sesuai dengan penalaran dan didukung oleh bukti atau informasi. Orang yang memiliki keterampilan berpikir kritis, akan mampu mengevaluasi, membedakan dan menentukan apakah suatu informasi benar atau salah. Berpikir kreatif lebih menekankan untuk menghasilkan karya atau inovasi dari karya yang sudah ada sehingga mengahsilkan produk atau sistem baru atau rekayasa baru. Kemampuan kerja sama merupakaan suatu yang harus dimiliki oleh setiap orang untuk mencapai tujuan bersama.

Dari dua aspek ini perlu adanya suatu model yang mendukung agar dua aspek tersebut dapat terlihat pada diri peserta didik. Salah satu model pembelajaran yang dapat diimplementasikan untuk 
melatihkan keterampilan berpikir kritis peserta didik adalah pendekatan STEM (Science, Tecnology, Engineering, Mathematic). Pendekatan ini sebagai pendekatan interdisiplin pada pembelajaran, yang di dalamnya peserta didik menggunakan sains, teknologi, engineering, dan matematika dalam konteks nyata. Pendidikan STEM sebagai suatu pendekatan interdisiplin pada pembelajaran memberikan peluang kepada guru untuk memberi gambaran kepada peserta didik pentingnya konsep, prinsip, dan teknis dari sains, teknologi, engineering, dan matematika digunakan dalam konteks nyata secara terintegrasi dalam pengembangan produk, proses, dan sistem yang digunakan dalam kehidupan seharihari. Melalui pendekatan STEM diharapkan bisa membentuk sumber daya manusia (SDM) yang mampu bernalar dan berpikir kritis, logis, kreatif, dan sistematis, serta meningkatkan kemampuan kumnikatif, kolaboratif, atau pemecahan masalah, sehingga mampu menghadapi tantangan global serta mampu meningkatkan perekonomian negara nanti.

Pendidikan STEM memberi pendidik peluang untuk menunjukkan kepada peserta didik betapa konsep, prinsip, dan teknik dari STEM digunakan secara terintegrasi dalam pengembangan produk, proses, dan sistem yang digunakan dalam kehidupan sehari-hari mereka. Oleh karena itu, definisi pendidikan STEM diadopsi sebagai pendekatan interdisiplin pada pembelajaran (Reeve, 2013). Dalam pembelajaran berbasis STEM peserta didik menggunakan sains, teknologi, rekayasa, dan matematika dalam konteks nyata yang menghubungkan sekolah, dunia kerja, dan dunia global guna mengembangkan literasi STEM yang memungkinkan peserta didik mampu bersaing dalam abad ke- 21 . Dari latar belakang diatas, penelitian ini difokuskan pada, "Implementasi Pembelajaran Berbasis STEM dalam Meningkatkan Kemampuan Siswa dalam Berpikir Kritis, Kreatif dan Bekerjasama.”

\section{B. METODE}

1) Jenis Desain penelitian

Desain penelitian dengan menggunakan siklus PTK menggunakan 2 siklus.

2) Subjek Penelitian

Seluruh peserta didik pada kelas VIIA SMP Negeri 4 Sibulue sejumlah 22 orang.

3) Waktu dan tempat

Penelitian ini dilakukan di SMP Negeri 4 Sibulue Kabupaten Bone Provinsi Sulawesi Selatan bulan Februari- Maret tahun 2018.

4) Teknik Pengumpulan data

Teknik pengumpulan data dengan menggunakan tes dan lembar observasi

5) Teknik analisis data

Teknik analisis data dengan menggunakan analisis kuatitatif dan kualitatif 


\section{HASIL DAN PEMBAHASAN}

1. Strategi Pembelajaran

\section{Siklus I}

\section{pertemuan pertama}

Melakukan pembelajaran Unit Pembelajaran STEM Pembangkit Listrik Tenaga Minihidro (PLTMH) guru menanyangkan video, peserta didik mengamati dan mendiskusikan video

$>$ Setelah berdiskusi dalam kelompok, siswa ditugaskan untuk mencari referensi tambahan tentang dan melakukan selain perilaku yang terdapat dalam lembar pengamatan.

> Mengomunikasikan hasil diskusi mereka melalui prersentasi masing-masing kelompok.

$>$ Guru merefleksi dan memberi penguatan terhadap proses pembelajaran yang telah dilakukan pada hari ini.

$>$ Agar pembelajaran lebih bermakna, maka guru memotivasi kepekaan sosial siswa agar nilai-nilai karakter yang telah didiskusikan tadi dapat diamalkan dan ditindak lanjuti pada proses pembelajaran

\section{Pertemuan kedua}

$>$ Pada kegiatan inti guru menanyakan hasil perkembangan pembuatan PLTMH

$>$ Siswa berkelompok merakit sesuai rancangan yang telah dibuat.

$>$ Untuk merespon tayangan vidio yang telah diamati, maka diadakan tanya jawab guru dan siswa maupun siswa dengan siswa.

$>$ Untuk lebih mengefektifan kepekaan sosial siswa dari tayangan vidio tadi kaitannya dengan aktivitas pembelajaran baik di sekolah maupun dalam masyarakat, maka guru menuntun pada lembar kerja siswa (lembar kerja individu).

$>$ Guru berkeliling membaca seluruh LKS. Dan memilih salah satu LKS yang dianggap paling bagus

$>$ Lima terbanyak yang dipilih oleh siswa akan mendapat reword oleh guru, namun sebelumnya dipresentasikan di depan kelas.

$>$ Guru memberi penguatan dan merefleksi kegiatan pembelajaran pada hari ini.

$>$ Agar pembelajaran lebih bermakna, maka guru memotivasi kepekaan sosial siswa agar nilai-nilai karakter yang telah ajarkan

Sebagai tindak lanjut, siswa diberi tugas pekerjaan rumah memperbaiki hasil karya yang telah dibuat dan diujicoba dan mencari potret nilai-nilai karakter budaya bangsa dalam masyarakat dan diapresiasi sendiri oleh siswa.

\section{Siklus II}

\section{Pertemuan ketiga}

$>$ Pada kegiatan inti guru menanyakan hasil perkembangan ujicoba PLTMH

$>$ Siswa berkelompok merakit sesuai perbaikan rancangan yang telah dibuat. 
Untuk merespon tayangan video yang telah diamati, maka diadakan tanya jawab guru dan siswa maupun siswa dengan siswa.

Untuk lebih mengefektifan kepekaan sosial siswa dari tayangan video tadi kaitannya dengan aktivitas pembelajaran baik di sekolah.

- Guru berkeliling membaca seluruh LKS. Dan memilih salah satu LKS yang dianggap paling bagus

> Lima terbanyak yang dipilih oleh siswa akan mendapat reward oleh guru, namun sebelumnya dipresentasikan di depan kelas.

Guru memberi penguatan dan merefleksi kegiatan pembelajaran pada hari ini.

\section{Pertemuan keempat}

$>$ Pada kegiatan inti guru menanyakan hasil perkembangan ujicoba PLTMH pada pertemuan sebelumnya

$>$ Siswa berkelompok merakit sesuai perbaikan rancangan yang telah dibuat.

> Siswa Memperbaiki hasil pekerjaannya

$>$ Lima terbanyak yang dipilih oleh siswa akan mendapat reward oleh guru, namun sebelumnya dipresentasikan di depan kelas.

Guru memberi penguatan dan merefleksi kegiatan pembelajaran pada hari ini.

Dalam upaya membiasakan siswa berpikir dan berprilaku positif dalam setiap melakukan aktifitas olahraga, maka dalam kegiatan proses belajar-mengajar di lapangan, kami melakukan antisipasi dengan melakukan pengamatan secara intensip. Kami melakukan catatan-catatan jurnal setiap praktek olahraga di lapangan sebagai bahan evaluasi dan melakukan perbaikan terhadap pembinaan aspek moralitas siswa secara berkesinambungan.

Memberikan penghargaan kepada siswa yang berprestasi adalah merupakan suatu kebanggan tersendiri terhadap prestasi yang mereka raih. Dan yang terpenting bahwa dengan penghargaan tersebut siswa merasa dihargai oleh guru, oleh karena itu dampak penghargaan ini kepada diri siswa adalah mendorong siswa untuk belajar dan berbuat baik, oleh karena itu siswa yang diberikan penghargaan adalah siswa yang teridentifikasi memiliki sikap dan tingkah laku, serta sopan santun yang baik selama mengikuti pelajaran.

\section{Hasil Yang Dicapai}

Hasil yang dicapai terhadap inplementasi dari best paractice yang telah dilakukan dapat dijelaskan sebagai berikut:

1) Hasil pengamatan aktivitas peserta didik

Pengamatan dilakukan oleh dua orang pengamat terhadap peserta didik. prosedur pengamatan yang dilakukan adalah pengamat melakukan pengamatan terhadap aktivitas peserta didik yang muncul dan mengisi lembar pengamatan yang disediakan. Frekuensi aktivitas peserta didik selama tiga kali pertemuan terangkum pada Gambar 1. 


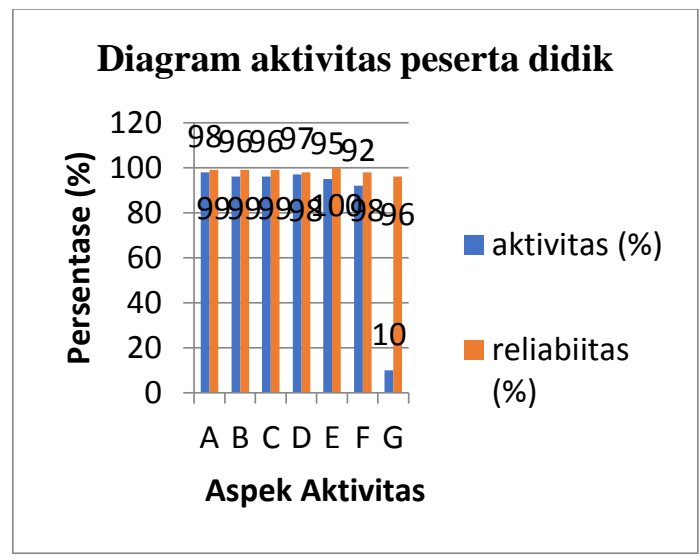

Gambar 1 Diagram hasil pengamatan rata-rata aktivitas peserta didik

Keterangan Aspek Gambar 1 adalah: A: Mendengarkan/memperhatikan penjelasan guru; B: Membaca buku peserta didik dan LKPD; C: Mengerjakan LKPD dan melakukan diskusi kelompok; D: Melakukan pengamatan dengan teman kelompok; E: Berlatih melakukan keterampilan berpikir kritis (KBK); F: Menyajikan atau menanggapi hasil kerja kelompok; G: Prilaku yang tidak relevan dengan PBM.

2) Hasil Pengamatan keterlaksanaan perangkat pembelajaran

Tujuan utama analisis data keterlaksanaan perangkat pembelajaran adalah untuk mengetahui keterlaksanaan perangkat dalam proses pembelajaran. Dalam mengobservasi keterlaksanaan perangkat, peneliti menggunakan dua orang pengamat.

Berdasarkan hasil analisis data observasi pengamat tentang keterlaksanaan perangkat pembelajaran dari lima kali pertemuan dapat dirangkum gambar 2 .

Berdasarkan data hasil pengamatan pada Gambar 2, terlihat bahwa keterlaksanaan perangkat pembelajaran berada pada rata-rata $\mathbf{M}=1,98$. Hal ini menunjukkan bahwa semua komponen yang diamati pada pelaksanaan perangkat pembelajaran berbasis STEM terlaksana seluruhnya dengan koefisien reliabilitas $99 \%$.

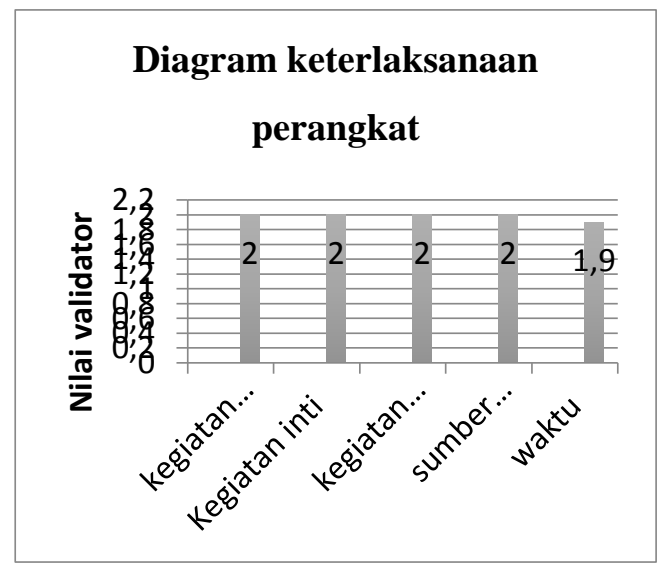

Gambar 2. Diagram hasil keterlaksanaan perangkat pembelajaran berbasis STEM 


\section{3) Hasil Respon Peserta Didik}

Analisis respon pesrta didk meliputi respon pesrta didik terhadap proses pembelajaran dan perangkat pembelajaran yang meliputi: $\mathrm{BPD}, \mathrm{LKPD}$, dan proses pembelajaran yang dituangkan dalam angket respon peserta didik.

Hasil analisis data respon peserta didik terhadap perangkat dan pelaksanaan pembelajaran dapat dilihar secara digram pada Gambar 3.

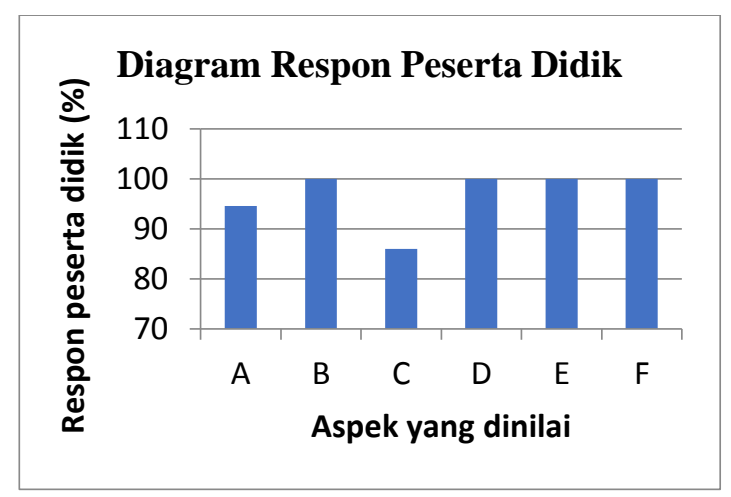

Gambar 3. Diagram hasil respon peserta didik terhadap perangkat dan pelaksanaan pembelajaran.

Keterangan Aspek: A: Kesenangan komponen, B: Kebaruan komponen, C: Kemudahan komponen, D: Ketertarikan pembelajara E: Kejelasan bahasa, F: Minat

4) Hasil Analisis tes keterampilan berpikir kritis

Untuk mengetahui peningkatan keterampilan berpikir kritis (KBK) peserta didik, maka dilakukan analisis dari skor pre tes dan post tes dengan menggunakan rumus N-Gain. Peningkatan keterampilan berpikir kritis peserta didik antara siklus I dan siklus II dapat digambarkan dalam bentuk diagram seperti Gambar 4.

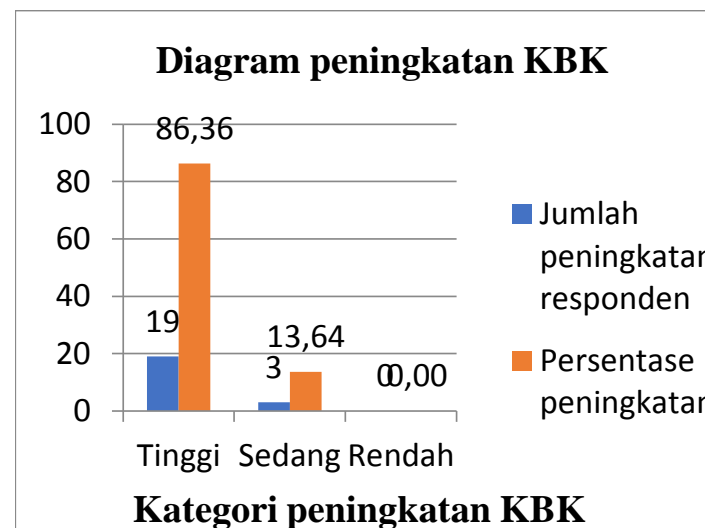

Gambar 4. Rata-rata peningkatan keterampilan berpikir kritis (KBK) antara siklus dan siklus II. 
Distribusi frekuensi analisis peningkatan keterampilan berpikir kritis (KBK) peserta didik dapat dilihat pada Tabel 1

Tabel 1 Distribusi Frekuensi Peningkatan KBK Peserta Didik

\begin{tabular}{rlccc}
\hline N-Gain & Kategori & Frekuensi & Persentase(\%) \\
\cline { 2 - 5 } $\boldsymbol{g}>0,7$ & tinggi & 19 & 86,36 \\
$\mathbf{0 , 3} \leq \boldsymbol{g} \leq \mathbf{0 , 7}$ & sedang & 3 & 13,64 \\
$\mathbf{0} \leq \boldsymbol{g} \leq \mathbf{0 , 3}$ & rendah & 0 & 0 \\
\hline
\end{tabular}

Dari Gambar 4 dan Tabel 1 dapat dijelaskan bahwa peningkatan rata-rata keterampilan berpikir kritis (KBK) ada 19 orang $(86,36 \%)$ berada dalam kategori tinggi, ada 3 orang $(13,64 \%)$ berada dalam kategori sedang, dan tidak ada peserta didik dalam kategori rendah. Sehingga dapat dikatakan bahwa peningkatan rata-rata keterampilan berpikir kritis (KBK) berada dalam kategori tinggi.

Pencapaian kompetensi keterampilan berpikir kritis (KBK) peserta didik pada materi PLTMH dilihat dari aspek ketuntasan belajar setelah diterapkan pembelajaran berbasis keterampilan berpikir kritis (KBK) dapat dilihat pada Tabel 2.

Tabel 2 Deskripsi ketuntasan KPS peserta didik

\begin{tabular}{cccc}
\hline Nilai & Kategori & $\begin{array}{l}\text { Frekuensi } \\
\text { Siklus I } \\
\text { Siklus II }\end{array}$ & $\begin{array}{c}\text { Persentase } \\
(\%) \\
\text { Pretest } \\
\text { posttest } \\
\end{array}$ \\
& & 0 & 0 \\
$52 \leq \mathrm{N}$ & Tuntas & 22 & 100 \\
$\leq 100$ & & 22 & 100 \\
$0 \leq \mathrm{N}<$ & Tidak & 0 & 0 \\
72 & Tuntas & 0 & \\
\hline
\end{tabular}

Berdasarkan Tabel 2 dapat dijelaskan bahwa ketuntasan belajar keterampilan berpikir kritis (KBK) peserta didik setelah diterapkan pembelajaran berbasis STEM mencapai $100 \%$ atau tuntas semua dari sebelumnya tidak tuntas semua.

5) Hasil Analisis peningkatan kreativitas dan kerjasama

Peningkatan keterampilan berpikir kritis peserta didik antara Siklus I dan Siklus II dapat digambarkan dalam bentuk diagram seperti Gambar 5. 


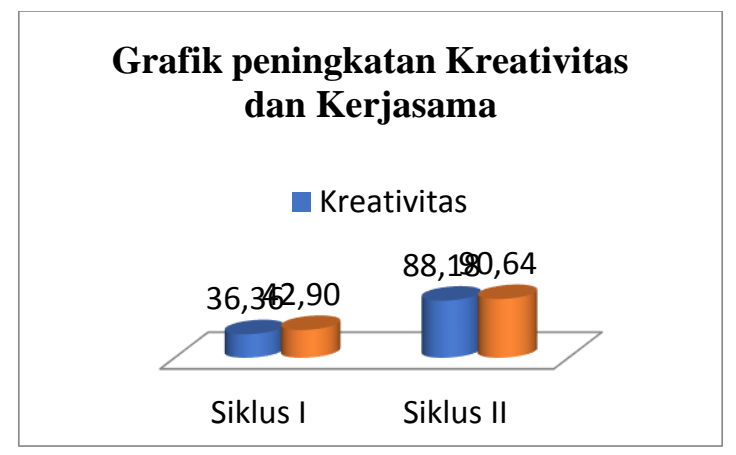

Gambar 5 Rata-rata peningkatan kreativitas dan kerjasama pre tes dan post tes.

Dari Gambar 5 dapat dijelaskan bahwa nilai rata-rata skor keativitas pada tes awal 36,36 menjadi 88,18 pada saat tes akhir setelah diterapkan pembelajaran STEM, sedangkan rata-rata skor kerjasama pada tes awal 42,90 menjadi 90,64 pada tes akhir. Sehingga dapat dikatakan bahwa kreativitas dan kerjasama peserta didik mengalami peningkatan yang signifikan.

Setelah implementasi pembelajaran STEM diterapkan kemampuan berpikir kritis siswa meningkat, kemampuan berpikir kreatif (kreativitas) juga meningkat ditandai dengan menghasilkannya rancangan dan produk PLTMH, kemampuan kerjasama peserta didik juga meningkat, selain itu kecenderungan sifat negatif di atas dapat diminimalisir bahkan berdasarkan pengamatan kami seharihari khususnya dalam pembelajaran maupun aktifitas sehari-hari terjadi peningkatan moralitas siswa secara signifikan. Dari hasil pekerjaan siswa melalui angket tersebut mencerminkan bahwa secara umum siswa mempunyai sikap moral yang baik, terlihat dari hasil pekerjaan dari 22 siswa yang di uji melalui angket 15 siswa yang menjawab sangat senang, 7 siswa yang menjawab senang. Dengan demikian pada umumya siswa senang dengan pembelajaran ini.

\section{SIMPULAN}

Implementasi Pembelajaran STEM dapat meningkatkan pemahaman konsep, keterampilan berpikir kritis dan kreatif dan kemampuan kerjasama peserta didik. Selain itu potret nilai-nilai karakter budaya bangsa dalam pembelajaran dapat meningkatkan aspek sikap positif siswa, baik sikap dalam melakukan aktifitas di sekolah maupun aktifitas dalam kehidupan sehari-hari. Hal ini didasarkan pada data yang diperoleh dari hasil penilaian yang telah dilakukan melalui pengamatan, angket, maupun respon siswa terhadap pembelajaran ini sangat positif.

\section{DAFTAR RUJUKAN}

Bybee, R. W. 2010. Advancing STEM education: A 2020 vision. Technology and Engineering Teacher, 70(1), 30-35.

Bybee, R. W. 2013. The case for STEM education: Challenges and opportunity. Arlington, VI: National Science Teachers Association (NSTA) Press. 
Ennis, R.H. 1985. Critical thinking and the curriculum. National Forum, 65, 28-31

Ennis, Robert H. 1996. Critical Thingking. New Jersey: Simon \& Schuster/A Viacom Company

Filsaisme, D.K. 2008. Menguak Rahasia Berpikir Kritis dan Kreatif. Jakarta: Prestasi Pustaka. Fisher, Alec. 2009. Berpikir kritis. Jakarta: Erlangga

Zamroni dan Mahfuz. 2009, Panduan Teknis Pembelajaran yang Mengembangkan Critical Thinking. Jakarta: Kencana. 